\title{
RECHTSREGEL
}

Jurnal Ilmu Hukum Vol 1, No 2 Desember 2018

P-ISSN 2622-6235, E-ISSN 2622-6243,

rjih_fh@unpam.co.id

\section{TINDAK PIDANA PENGANIAYAAN YANG \\ DILAKUKAN OLEH APARAT KEPOLISIAN \\ DALAM KASUS SALAH TANGKAP DIHUBUNGKAN \\ DENGAN PASAL 351 KUHP}

Tubagus Ahmad Ramadan

Fakultas Hukum, Universitas Pamulang

Email : ahmadnanggroe@gmail.com

Received: - /Revised: - /Accepted: Des 2018

\begin{abstract}
ABSTRAK
Aparat penegak hukum mempunyai kewenangan melakukan upaya paksa (dwang middelen) dalam rangka penegakan hukum pidana. Penegakan hukum pidana melalui upaya paksa adalah suatu tindakan hukum yang dilakukan oleh aparat penegak hukum dalam lingkup tugas dan tanggung jawabnya berdasarkan peraturan yang berlaku. Tindakan hukum ini dapat mengurangi dan membatasi hak asasi seseorang antara lain penangkapan, penahanan, pengeledahan, penyitaan, dan pemeriksaan surat. Artinya apabila aparat penegak hukum melaksanakan hukum dengan tidak berdasarkan peraturan yang berlaku dalam hal menjalankan wewenangnya, maka tindakan itu pasti merupakan pelanggaran hak asasi manusia (HAM). Hal ini harus dihindari dalam penegakan hukum pidana di Indonesia karena pelanggaran HAM yang dilakukan penegak hukum dalam lingkup tugas dan wewenangnya dalam melakukan upaya paksa merupakan perusak kepercayaan masyarakat kepada hukum dan aparaturnya di Indonesia. Jika ini telah terjadi maka kepercayaan masyarakat akan aparat penegak hukum akan hilang. Seperti halnya Polisi yang mempunyai kewenangan upaya paksa penangkapan, dimana seringkali dijumpai upaya paksa penangkapan yang dilakukan Polisi itu disertai kelalaian yang dilakukan oleh polisi tersebut dalam proses penangkapannya. Salah tangkap merupakan pelanggaran hak asasi manusia berat. Karena upaya ini menundukkan orang yang tidak bersalah dijadikan bersalah dan yang
\end{abstract}


lebih parahnya lagi sering kali terjadi salah tangkap ini disertai dengan kekerasan yang juga dilakukan oleh aparat penegak hukum dalam lingkup dan wewenangnya melakukan upaya paksa penangkapan

\title{
Kata Kunci : Tindak Pidana Penganiayaan, Salah Tangkap
}

\begin{abstract}
Law enforcement officials have the authority to carry out forced efforts (dwang middelen) in the context of criminal law enforcement. The enforcement of criminal law through forced efforts is a legal action perpetrated by law enforcement officers within the scope of their duties and responsibilities under applicable regulations. This legal action can reduce and limit one's human rights, such as arrest, detention, search, seizure, and letter examination. This means that if law enforcement officers implement the law by not according to the rules applicable in terms of exercising its authority, then the action must be a violation of human rights (HAM). This should be avoided in the enforcement of criminal law in Indonesia because human rights violations committed by law enforcement in the scope of duty and authority in conducting the forced effort are destructive of public trust to the law and its apparatus in Indonesia. If this has happened then the public's trust in law enforcement officials will be lost. Just as the Police have the authority to forcibly arrest the attempts, which are often encountered by the Police's attempted arrest, accompanied by negligence by the police in the process of his arrest. False arrests are a gross violation of human rights. Because this attempt to subdue innocent people is made to be guilty and, even worse, it is often misunderstanded that this is accompanied by violence perpetrated by law enforcement officials in the scope and authority of attempting to forcibly arrest. Therefore, criminal law enforcement must be based on applicable legislation. This thesis will discuss the case of wrongful arrests conducted by police officers against victims J.J. Rizal who in the process of his arrest, J.J Rizal got persecution from the defendants who are members of the police. Where this case has been decided in the District Court of Depok with the decision number: 80 / Pid.B / 2010 I PN.Dpk. In this thesis will be analyzed more deeply about
\end{abstract}


the element of offense of criminal acts of persecution regulated in the Criminal Code.

Keywords : Criminal Act Persecution, False Caught 


\section{RECHTSREGEL}

Jurnal Ilmu Hukum Vol 1, No 2 Desember 2018

P-ISSN 2622-6235, E-ISSN 2622-6243,

rjih_fh@unpam.co.id

\section{PENDAHULUAN}

Undang-undang Dasar 1945 menentukan bahwa negara berkewajiban melindungi segenap bangsa Indonesia dan seluruh tumpah darah Indonesia. Perlindungan yang dimaksud meliputi perlindungan masyarakat terhadap kejahatan dan hal-hal lain yang memberi potensi timbulnya hal itu sehingga negara berkewajiban mengadakan pencegahan dan penanggulangan kejahatan. Dewasa ini setiap kali para ahli hukum pidana membicarakan pencegahan dan penanggulangan kejahatan, hal tersebut dilakukan secera komprehensif termasuk didalamnya adalah penegakan hak asasi manusia. Artinya, masalah pencegahan dan penanggulangan kejahatan harus disertai dengan penegakan hak asasi manusia.

Penegakan hak asasi manusia sangat terkait dengan penegakan hukum pidana, oleh karenanya, penghormatan hak asasi manusia bukan hanya berlaku di Indonesia, tetapi berlaku universal. Hak asasi manusia tersebut dirumuskan dalam suatu naskah internasional yang diwujudkan dalam bentuk Universal Declaration of Human Rights 10 December 1948 (Deklarasi Universal Hak Asasi Manusia) oleh negara yang tergabung dalam Perserikatan Bangsa-Bangsa (PBB) di Paris. ${ }^{1}$ Dengan demikian masalah kejahatan dilihat sebagai masalah

1 Muladi, Hak Asasi Manusia, Konsep, Implikasi dalam persepektif Hukum dan Masyarakat, (Bandung: Refika Aditama, 2005), hal 39 


\section{Tubagus Ahmad Ramadan}

sosial $^{2}$ yang penanganannya tidak semata-mata menggunakan hukum pidana saja tetapi penegakan hukum pidana yang disertai dengat penegakan hak asasi manusia. Dengan demikian penerapan sanksi pidana tersebut sesuai dengan pengertian hukum pidana secara objektif. Artinya, penerapan objektif yang disebut iuspoenale yakni sejumlah peraturan yang mengandung larangan-larangan atau keharusan-keharusan terhadap pelanggarannya diancam dengan hukuman tetapi hak asasi manusia tetap ditegakkan. ${ }^{3}$

Aparat penegak hukum mempunyai kewenangan melakukan upaya paksa (dwang middelen) dalam rangka penegakan hukum pidana. Penegakan hukum pidana melalui upaya paksa adalah suatu tindakan hukum yang dilakukan oleh aparat penegak hukum dalam lingkup tugas dan tanggung jawabnya berdasarkan peraturan yang berlaku. Tindakan hukum dapat mengurangi dan membatasi hak asasi seseorang seperti antara lain penangkapan, penahanan, penggeledahan, penyitaan dan pemeriksaan surat. Artinya, apabila aparat penegak hukum melaksanakan hukum dengan tidak berdasar peraturan yang berlaku dalam hal menjalankan wewenangnya, maka tindakan itu pasti merupakan pelanggaran Hak Asasi Manusia (HAM). ${ }^{4}$

\footnotetext{
${ }^{2}$ Ibid, hal 39

${ }^{3}$ Andi Hamzah, Delik-delik Tertentu di Dalam KUHP, (Jakarta: Sinar Grafika, 2009), hal 30

${ }^{4}$ O.C. Kaligis, Perlindungan Hukum Atas Hak Tersangka, Terdakwa, dan Terpidana, (Bandung: Penerbit Alumni, 2006) hal 370
} 
Kitab Undang-Undang Hukum Acara Pidana (KUHAP) yang terdapat pada Pasal 1 butir 1 yang berbunyi sebagai berikut: penyidik adalah pejabat Polisi Negara Republik Indonesia atau Pejabat Pegawai Negeri Sipil tertentu yang diberi wewenang khusus oleh undangundang untuk melakukan penyidikan, selain penyidik dalam KUHAP dikenal pula penyidik pembantu, ketentuan hal ini terdapat pada pasal 1 butir 3 KUHAP, yang menyebutkan bahwa: penyidik pembantu adalah Pejabat Kepolisian Negara Republik Indonesia yang diberi wewenang tertentu dapat melakukan penyidikan yang diatur dalam undang-undang ini. ${ }^{5}$

Sebagaimana diketahui bahwa KUHAP menempatkan tersangka atau terdakwa dalam posisi yang harus diperlakukan sesuai dengan nilai-nilai luhur kemanusiaan. Dalam pelaksanaan penegak hukum, hakhak asasi yang melekat pada diri tersangka dan terdakwa tidak boleh dikurangi. Berdasarkan KUHAP, hak-hak utama tersangka atau terdakwa harus dijunjung tinggi yakni :6

1. Persamaan kedudukan serta kewajiban di hadapan hukum.

2. Praduga tak bersalah (Presumption of Innocence).

3. Penangkapan atau penahanan harus didasarkan bukti permulaan yang cukup. hal 78

${ }^{5}$ Yesmil Anwar dan Adang, Sistem Peradilan Pidana, (Bandung: Widya Padjajaran, 2009), ${ }^{6}$ O.C. Kaligis, Op.Cit, hal 370 
4. Kesalahan harus dibuktikan di sidang pengadilan yang berimbang (fair trail).

5. Tidak boleh ada campur tangan dari pemerintah atau kekuasaan manapun.

6. Hak mempersiapkan pembelaan secara dini.

Jika penegakan hukum tidak menyertakan atau memperhatikan hak-hak di atas berarti di dalam proses penegakan hukum di sini telah terjadi kesalahan yang berujung pada pelanggaran Hak Asasi Manusia. Salah satu kasus yang serius terjadi adalah salah tangkap. Salah tangkap yang merupakan pelanggaran Hak Asasi Manusia berat. Karena upaya ini mendudukkan orang yang tidak bersalah dijadikan bersalah dan yang lebih parahnya lagi sering kali terjadi salah tangkap ini disertai dengan kekerasan yang juga dilakukan oleh aparat penegak hukum dalam lingkup dan wewenangnya melakukan upaya paksa dan upaya penegakan hukum lainnya. Oleh karena itu, penegakan hukum pidana harus berdasarkan perundang-undangan yang berlaku. Jika menyimpang dari peraturan perundang-undangan maka sudah pasti di dalam penegakan hukum tersebut telah terjadi kesalahan.

Masalah penangkapan merupakan upaya paksa (dwang middelen) yang menurut Kelsen merupakan legalitas yang diberikan oleh peraturan perundangundangan atau hukum positif. ${ }^{7}$ Lebih lanjut dijelaskan oleh Kelsen bahwa penggunaan upaya paksa (dwang middelen) bertujuan untuk keamanan, keadilan, dan

${ }^{7}$ Andi Hamzah, Op.Cit, hal 21 
persamaan harus dicapai melalui ancaman pencabutan kehidupan, kebebasan, atau harta benda seseorang, dengan kata lain paksaan digunakan untuk mencegah penggunaan paksaan oleh masyarakat. ${ }^{8}$

Namun demikian, jika proses penagkapan itu bukan karena pelanggaran dan/atau kejahatannya alias salah tangkap, maka jelas ini merupakan suatu tindakan melanggar hukum yang dilakukan penegak hukum dalam lingkup dan wewenangnya melakukan upaya paksa panangkapan, apalagi jika di dalamnya juga disertai dengan kekerasan.

Kebanyakan kasus salah tangkap di Indonesia itu merupakan pelanggaran terhadap asas praduga tak bersalah yang dapat mengundang perhatian besar masyarakat baik di tingkat nasional maupun internasional. Seperti kasus salah tangkap, salah menahan, perlakuan tindakan kekerasan dan penyiksaan (violence and torture) oleh para penegak hukum. Seperti yang dialami oleh korban J.J. Rizal yang menjadi korban salah tangkap karena kelalaian polisi dalam melakukan penagkapan. Kejadian tersebut dialami oleh Rizal pada hari Sabtu tanggal 5 Desember 2009 di depan Depok Town Square. Saat itu Rizal sedang berjalan kaki melewati jalan raya Margonda tepatnya di depan pusat perbelanjaan Depok Town Square yang saat itu kebetulan di jalan tersebut barusaja terjadi pencopetan di mana aparat

${ }^{8}$ O.C. Kaligis, Op.Cit, hal 390 
kepolisian masih melakukan penyelidikan untuk mencari kawanan pencopet yang belum tertangkap.

Tanpa bukti permulaan yang cukup, tiba-tiba Rizal disergap oleh Antoni, Supratman, dan Muhammad Syahrir yang ketiganya merupakan anggota kepolisian yang menduga Rizal adalah salah satu kawanan pencopet yang baru saja tertangkap. Rizal meronta-ronta dan berteriak meminta tolong karena langsung disergap oleh tiga orang yang sama sekali tidak dikenalnya, meskipun ketiga orang tersebut sudah memberitahukan bahwa mereka adalah polisi tetapi Rizal tetap meronta-ronta sambil berteriak meminta tolong. Karena perilaku Rizal itu maka ketiga polisi yang menyergap tadi melakukan kekerasan terhadap Rizal dengan tujuan agar Rizal tenang dan dapat dengan mudah dibawa ke kantor polisi. Alhasil karena kekerasan yang dilakukan ketiga polisi tersebut akhirnya Rizal dapat dibawa ke Polsek Beji untuk diperiksa lebih lanjut. Sampai di polsek Beji baru diketahui bahwa ketiga polisi tadi telah melakukan salah tangkap kerena pencopet yang sebenarnya sudah tertangkap terlebih dahulu ternyata tidak mengenali Rizal. Dengan demikian Rizal dibebaskan. Selanjutnya Rizal melaporkan kejadian yang dialami ke Polda Metro Jaya.

Salah tangkap ini merupakan kesalahan aparat penegak hukum yang tidak berdasarkan asas legalitas didalam menjalankan tugasnya. Artinya, kepolisian telah mengabaikan apa yang diatur dalam Pasal 18 KUHAP tentang tata cara penangkapan. Apalagi kesalahan dalam penangkapan diatas disertai juga dengan kekerasan yang 
berakibat luka-luka pada korban J. J. Rizal. Dengan demikian setelah tebukti bahwa J. J. Rizal merupakan korban salah tangkap maka J. J. Rizal harus mendapatkan hak-haknya kembali sebelum dia ditangkap karena kesalahan Polisi. Dan terhadap polisi yang melakukan salah tangkap tersebut harus diberikan sanksi administratif dan sanksi hukum pidana sesuai dengan pelanggaran pidana yang dia lakukan terhadap korban J. J. Rizal. Hal tersebut harus dilakukan agar keadilan yang harus ditegakan lewat media hukum benar-benar terjadi dan bukan hanya idealisme semata.

Akibat perbuatan para terdakwa tersebut Rizal mengalami luka memar. Dari hasil visum oleh Dokter Robby Al Amin yaitu dokter pada Rumah Sakit Mitra Keluarga yang menerangkan bahwa pada hari Minggu tanggal 6 Desember 2009 pukul 03:29 WIB telah memeriksa seseorang pasien laki-laki :

Nama: J. J. Rizal

Umur : 35 tahun

Alamat : Jalan Pala No.4B Beji Timur - Depok

Terhadap kasus semacam ini yang terbukti salah tangkap karena kelalaian aparat penegak hukum, korban tersebut harus mendapatkan hak-haknya antara lain rehabilitasi nama baik, ganti rugi, dan hak-hak lain untuk mengembalikan hak asasinya yang diambil paksa oleh hukum karena kekeliruan atau kelalaian aparat penegak hukumnya.

PERMASALAHAN 
Bentuk tindak pidana penganiayaan yang terjadi pada korban salah tangkap yang dilakukan oleh Aparat Kepolisian diwilayah hukum Polsek Beji Kota Depok dan fakta penyebab terjadinya proses salah tangkap yang dilakukan oleh para terdakwa diwilayah hukum Polsek Beji Kota Depok?

\section{METODOLOGI PENELITIAN}

\section{Grand Theory (Teori Dasar)}

Adapun Grand theory yang digunakan dalam penulisan ini adalah Negara Hukum. Grand theory, merupakan dasar lahirnya teori-teori lain dalam berbagai level, karena teori-teori ini berada pada level makro.

Di zaman modern, konsep Negara hukum di Eropah Kontinental dikembangkan antara lain oleh Immanuel Kant, Paul Laband, Julius Stahl, Fichte, dan lain-lain dengan menggunakan istilah Jerman, yaitu "rechtsstaat". Sedangkan dalam tradisi Anglo Saxon, konsep Negara hukum dikembangkan atas kepeloporan A.V. Dicey dengan sebutan "the rule of law".

Bagi konsepsi Negara Hukum "rechtsstaat". Penegakan hukum berarti penegakan hukum yang ditulis dalam Undang-Undang sesuai dengan paham Legisme yaitu bahwa hukum identic dengan Undang-Undang sehingga dari situlah diharapkan adanya kepastian hukum. Adapun konsepsi Negara Hukum "the rule of law" penegakan hukum tidak berarti penegakan hukum yang ditulis dalam Undang-Undang semata, bahkan hukum tertulis tersebut lebih diterima untuk disimpangi oleh 
Hakim jika memang dirasakan tidak memenuhi rasa keadilan hukum.

Gagasan, cita-cita, konsep atau ide Negara Hukum, selain terkait dengan konsep "rechtsstaat" dan "the rule of law", juga berkaitan dengan konsep "nomocracy" yang berasal dari perkataan"nomos"dan "cratos". Perkataan nomokrasi itu dapat dibandingkan dengan "demos" dan "cratos" atau "kratien" dalam demokrasi. "nomos" berarti normal, sedangkan "cratos" adalah kekuasaan, sebagai faktor penentu dalam penyelenggaraan kekuasaan adalah norma atau hukum. Karena itu, istilah nomokrasi itu berkaitan erat dengan ide kedaulatan hukum atau prinsip hukum sebagai kekuasaan tertinggi. Dalam istilah Inggeris yang dikembangkan oleh A.V.Dicey, hal itu dapat dikaitkan dengan prinsip "rule of law" yang berkembang di Amerika Serikat menjadi jargon "the Rule of Law, and not of Man”. Yang sesungguhnya dianggap sebagai pemimpin adalah hukum itu sendiri, bukan orang 


\section{RECHTSREGEL}

\section{PEMBAHASAN}

\section{Kasus Salah Tangkap}

Seperti yang dialami oleh korban J. J. Rizal yang menjadi korban salah tangkap karena kelalaian Polisi dalam melakukan penangkapan. Kejadian tersebut dialami Rizal pada hari Sabtu tanggal 5 Desember 2009 didepan Depok Town Square. Saat itu Rizal sedang berjalan kaki melewati Jalan Raya Margonda tepatnya didepan pusat perbelanjaan Depok Town Square yang saat itu kebetulan dijalan tersebut baru saja terjadi pencopetan dimana aparat kepolisian masih melakukan penyelidikan untuk mencari kawanan pencopet yang belum tertangkap.

Tanpa bukti permulaan yang cukup, tiba-tiba Rizal disergap oleh Antoni (terdakwa I), Supratman (terdakwa II), dan Muhammad Syahrir (terdakwa III) yang ketiganya merupakan anggota kepolisian yang menduga Rizal adalah salah satu kawanan pencopet yang baru saja tertangkap. Rizal meronta-ronta dan berteriak meminta tolong karena langsung disergap oleh tiga orang yang sama sekali tidak dikenalnya, meskipun ketiga orang tersebut sudah memberitahukan bahwa mereka adalah Polisi tetapi Rizal tetap meronta-ronta sambil berteriak meminta tolong. Karena perilaku Rizal itu maka ketiga polisi yang menyergap tadi melakukan kekerasan terhadap Rizal dengan tujuan agar Rizal tenang dan dapat dengan mudah dibawa ke kantor Polisi. Alhasil karena kekerasan yang 
dilakukan ketiga polisi tersebut akhirnya Rizal dapat dibawa ke Polsek Beji untuk

diperiksa lebih lanjut. Sesampai di Polsek Beji baru diketahui bahwa ketiga polisi tadi telah melakukan salah tangkap karena pencopet yang sebenarnya yang sudah tertangkap terlebih dahulu ternyata tidak mengenali Rizal. Dengan demikian Rizal dibebaskan.

\section{Faktor-faktor Penyebab Terjadinya Salah Tangkap}

Adapun Fakto-faktor penyebab terjadinya salah tangkap yang akan dibahas dalam penulisan ini adalah sebagai berikut:

\section{A. Asas Legalitas}

Salah tangkap ini merupakan kesalahan dan kelalaian aparat penegak hukum yang tidak berdasarkan asas legalitas maksudnya legalitas tindakan kepolisian dalam menjalankan tugas dan wewenangnya tidak didasarkan pada suatu perundang-undangan yang mengatur, dimana polisi telah mengabaikan apa yang diatur dalam Pasal 18 KUHAP tentang tata cara penangkapan dimana seharusnya pada saat melakukan penangkapan Aparat Kepolsian harus menunjukkan kartu identitas, namun tidak bagi penangkapan terhadap korban Rizal pada saat sebelum penangkapan ke tiga pelaku langsung menyergap korban Rizal tanpa menunjukkan identitas dan langsung melakukan penggeledahan badan Serta mengeluarkan dan mengamankan barang-barang milik korban berupa 2 (dua) buah HP, dompet, dan satu bundal kunci. 


\section{Tubagus Ahmad Ramadan}

Sekalipun terdakwa sebagai anggota kepolisian bukanlah suatu alasan pembenar untuk melakukan kekerasan, karena sebagaimana diketahui dalam pola penanganan kasus yang berlaku di internal tubuh kepolisian tidak satupun adanya aturan atau perintah yang membenarkan tindakan seperti yang dilakukan oleh para terdakwa tersebut. Sebagaimana diketahui bahwa KUHAP menempatkan ke dalam posisi yang harus diperlakukan sesuai dengan nilai-nilai luhur kemanusiaan.

B. Kealpaan

Kealpaan yang dilakukan polisi dalam menjalankan wewenangnya melakukan upaya paksa dalam rangka penegakan hukum pidana. Kealpaan yang dimaksud seperti, penyidik menangkap orang yang awalnya diduga sebagai pelaku tindak pidana dan kemudian diketahui bahwa orang tersebut bukan pelaku yang disangkakan pihak penyidik sebagai pelaku tindak pidana. Penyidikan seperti ini mendorong hasil penyidikan yang tidak objektif tetapi lebih mengarah kepada unsur subjektif, kondisi ini menghasilkan penyidikan tidak proposional.

Dalam hal kealpaan pada diri para terdakwa terdapat:

a. Kekurangan pemikiran (penggunaan akal) yang diperlukan

b. Kekurangan pengetahuan

c. Kekurangan kebijaksanaan yang diperlukan

Kendala yang dihadapi dalam proses penyidikan masih kurangnya kemampuan pendidik menerapkan 


\section{Tubagus Ahmad Ramadan}

teknik-teknik dan taktik penangkapan, belum sepenuhnya dilaksanakan sesuai dengan ketentuan, sehingga sering ditemukan melakukan penangkapan tanpa menggunakan surat perintah penangkapan yang tidak sesuai dengan prosedur yang ada. Masih ditemukan adanya penyidik yang salah tangkap terhadap orang yang bukan pelaku kejahatan, akibat kurang jelinya penyidik atau terlalu gegabah dalam melaksanakan tugasnya. ${ }^{9}$

\section{Proses Hukum Bagi Aparat Kepolisian Yang Melakukan}

\section{Salah Tangkap}

Penegak hukum pidana melalui upaya paksa adalah suatu tindakan hukum yang dilakukan oleh aparat penegak hukum dalam lingkup tugas dan tanggung jawabnya berdasarkan peraturan yang berlaku. Tindakan hukum ini dapat mengurangi dan membatasi hak asasi manusia seperti antara lain penangkapan, penahanan, pengeledahan, penyitaan, dan pemeriksaan surat. Artinya apabila aparat penegak hukum melaksanakan hukum dengan tidak berdasarkan peraturan yang berlaku dalam hal menjalankan wewenangnya melakukan upaya paksa penangkapan, maka tindakan itu pasti merupakan pelanggaran hak asasi manusia (HAM) dan merupakan perusak kepercayaan masyarakat kepada aparaturnya di Indonesia.

Aparat penegak hukum yang melakukan salah tangkap tersebut harus diberikan sanksi yang tegas dari

${ }^{9}$ Yesmil Anwar dan Adang, Op.Cit, hal 183 


\section{Tubagus Ahmad Ramadan}

instasinya dan juga sanksi tegas yang diberikan dari hukum pidana sesuai dengan kekerasan yang para pelaku lakukan terhadap korban J.J. Rizal. Hal tersebut harus dilakukan agar keadilan yang harus ditegakkan lewat media hukum benar-benar terjadi dan bukan hanya idealisme semata.

Adapun Proses Hukum bagi ke 3 (tiga) pelaku sebagai Anggota Polri antara lain sebagai berikut:

1. Para pelaku dikenakan sanksi pelanggaran Disiplin Polri menurut pasal 9 Peraturan Pemerintah No. 2 Tahun 2003 tentang Peraturan Disiplin Anggota Polri, berupa:

a. Pelaku dijatuhi hukuman disiplin 21 hari kurungan. ${ }^{10}$

Hukuman disiplin diatas dapat dijatuhkan secara alternatif. Dijatuhkan secara alternatif, artinya memilih salah satu sanksi hukuman yang sesuai berdasarkan keadilan. ${ }^{11}$

2. Salah satu alternatif sanksi hukuman terhadap para terdakwa dengan tindak pidana penganiayaan kepada korban Rizal yaitu penganiayaan biasa yang diatur dalam Pasal 351 ayat (1) KUHP Jo. Pasal 55 Ayat (1) ke-1 yang berbunyi:

a. Menurut Pasal 351 ayat (1) Kitab Undang-undang Hukum Pidana:

"Penganiayaan diancam dengan pidana penjara paling lama dua tahun delapan bulan atau denda paling banyak tiga ratus rupiah”.

10 Terdapat di situs <bantuanhukum.or.id/.../626-coreng-hitam-di-wajah-bhayangkararek...>, diakses pada tanggal 8 Oktober 2012

${ }^{11}$ Sadjijono, Memahami Hukum Kepolisian, Cet. 1, (Yogyakarta: Laksbang, 2010), hal 209 
Tubagus Ahmad Ramadan

b. Menurut Pasal 55 Ayat (1) ke-1 Kitab Undang-undang Hukum Pidana:

"Mereka yang melakukan, yang menyuruh lakukan dan yang turut serta melakukan perbuatan”. 


\section{KESIMPULAN}

1. Bentuk tindak pidana penganiayaan yang terjadi pada korban salah tangkap yang dilakukan oleh Aparat Kepolisian diwilayah hukum Polsek Beji Kota Depok adalah bentuk tindak pidana penganiayaan biasa yang diatur dalam Pasal 351 ayat (1) KUHP dan juga penganiayaan itu dilakukan oleh para pelaku dengan bersama-sama atau penyertaan dalam melakukan tindak pidana seperti yang diatur dalam Pasal 55 ayat (1) ke-1 KUHP.

2. Fakta penyebab terjadinya proses salah tangkap yang dilakukan oleh Aparat Kepolisian diwilayah hukum Polsek Beji Kota Depok adalah dimana Kesalahan dan Kelalaian aparat penegak hukum yang tidak berdasarkan asas legalitas dan Kealpaan penyidik menangkap orang yang awalnya diduga sebagai pelaku tindak pidana dan kemudian diketahui bahwa orang tersebut bukan pelaku yang disangkakan.

\section{SARAN}

1. Dalam upaya paksa penangkapan, seharusnya para penyidik mentaati tata cara penangkapan yang diatur dalam pasal 18 KUHP dan tentunya penangkapan tidak boleh disertai dengan kekerasan.

2. Perlunya pendidikan sosialisasi terhadap masyarakat mengenai kewenangan melakukan upaya paksa yang dimiliki Penyidik dalam upaya penegakan hukum. Hal ini perlu dilakukan agar masyarakat tahu batasan aparat penegak hukum dalam melakukan upaya paksa. Sehingga masyarakat akan segera tahu jika aparat penegak hukum melewati batas kewenangannya dalam melakukan upaya paksa.

\section{DAFTAR PUSTAKA}

\section{Buku}

Andi Hamzah, Delik-delik Tertentu di Dalam KUHP. Jakarta: Sinar Grafika, 2009. 
Muladi, Hak Asasi Manusia, Konsep, Implikasi dalam Persepektif Hukum dan Masyarakat. Bandung: Refika Aditama, 2005.

O.C. Kaligis, Perlindungan Hukum Atas Hak Tersangka, Terdakwa, dan Terpidana. Bandung: Penerbit Alumni, 2006.

Sadjijono, Memahami Hukum Kepolisian. Yogyakarta: Laksbang, 2010. Yesmil Anwar dan Adang, Sistem Peradilan Pidana. Bandung: Widya Padjajaran, 2009.

\section{A. Situs}

<bantuanhukum.or.id/.../626-coreng-hitam-di-wajah-bhayangkararek...>,

diakses pada tanggal 8 Oktober 2012 